\title{
The Position of Mineral Nitrogen Fertilizer in Efficient Use of Nitrogen and Land: A Review
}

\author{
Jaap Jan Schröder \\ Plant Sciences Group, Wageningen University and Research Centre, Wageningen, The Netherlands \\ Email: jaap.schroder@wur.nl
}

Received 10 September 2014; revised 27 October 2014; accepted 22 November 2014

Copyright (C) 2014 by author and Scientific Research Publishing Inc. This work is licensed under the Creative Commons Attribution International License (CC BY). http://creativecommons.org/licenses/by/4.0/

c. (i) Open Access

\begin{abstract}
Our attitude towards mineral nitrogen ( $\mathrm{N}$ ) fertilizers is ambivalent. $\mathrm{N}$ fertilizers have on one hand increased our supply of food, feed and other bio-based raw materials tremendously and also improved the use efficiency of land and labor, but have on the other hand a negative impact on the quality of the environment and contributed to the depletion of fossil fuel reserves. This awareness has resulted in strong pleas to spend much more attention to the recycling of $\mathrm{N}$ containing downstream "wastes". It is, however, naive to assume that even perfect recycling suffices to offer the same number of people the same diet without inputs of "new" $N$, as inevitable losses of $\mathrm{N}$ make compensations indispensable. "New" $\mathrm{N}$ can be derived from either biological $\mathrm{N}$ fixation ("legumes") or from industrially fixed $\mathrm{N}$ ("fertilizer"). The existing literature provides no evidence that the use of $\mathbf{N}$ fertilizers is per se unsustainable, as these fertilizers can also be made from renewable forms of energy. Besides, soil health and human health appear sensitive for the dosage but not for the form of $\mathrm{N}$. It is yet imperative to reduce the input of "new" $\mathrm{N}$ as much as possible, so as to minimize adverse environmental effects. Measures to this end are a more precise assessment of crop $\mathrm{N}$ requirements, a better timing and positioning of $N$ inputs, and any measure supporting the acceptance of "wastes" by farmers. The present paper elaborates the above aspects.
\end{abstract}

\section{Keywords}

Mineral Fertilizer, Nitrogen, Phosphorus, Legumes, Manure, Environment, Efficiency

\section{Introduction}

Nitrogen $(\mathrm{N})$ is an essential constituent of all living creatures. Without $\mathrm{N}$ we would not exist, simply because 
there would be no food. However, once reactive forms of $\mathrm{N}$ are industrially synthesized to increase our provision with food, feed, fiber and biofuel, some decision makers and a part of the general public start questioning the necessity of these so-called mineral $\mathrm{N}$ fertilizers. Mineral fertilizers appear to have become emblematic for many aspects that people may have problems with, such as the increasing scale of fields and farms and the commensurate disappearance of landscape mosaics, loss of proximity and traceability of food production, loss of animal welfare, contamination of food by pesticides, and so on. The use of $\mathrm{N}$ fertilizer has in itself little to do with these specific objections. At the same time it would be incorrect to state that the use of $\mathrm{N}$ is without problems. It is definitely not. First, once applied, $\mathrm{N}$ is easily lost to the wider environment, regardless whether it stems from industrial fertilizers or from recycled "natural" products. Lost $\mathrm{N}$ can have negative impacts on the quality of air and water, as it is associated with the formation of smog and tropospheric ozone, global warming effects, depletion of stratospheric ozone and negatively affects the quality of groundwater and surface water. Lost $\mathrm{N}$ can thus have a serious impact on the health of plants, animals and men, on the quality of ecosystems and, in the end, on biodiversity [1] [2]. Moreover, the production of mineral fertilizer $\mathrm{N}$ is still largely based on the use of fossil fuels, although the energy consumption per unit fertilizer $\mathrm{N}$ produced, has drastically decreased in the course of time. Modern fertilizer N production facilities consume roundabout $35 \mathrm{MJ}$ ("one $\mathrm{m}^{3}$ natural gas") per kg $\mathrm{N}$ where they once needed several times that amount [3]. Fossil fuel remains a non-sustainable resource; however, its consumption contributes to the emission of greenhouse gases.

So, next to the indisputable beneficial effects of synthetic $\mathrm{N}$ fertilizers on human welfare by supplying more food, feed, fiber and biofuel [4], the losses of $\mathrm{N}$ confront us with dilemmas [5] [6]. Losses of $\mathrm{N}$ either in reactive forms $\left(\mathrm{NO}_{3}, \mathrm{NH}_{3}, \mathrm{~N}_{2} \mathrm{O}\right)$ or as inert elementary $\mathrm{N}_{2}$, can be minimized but are to a certain extent inevitable, as much in natural systems as in agriculture. Productivity in both systems can hence only be sustained if these losses are replenished with "new" reactive $\mathrm{N}$. The present paper intends to explain which role mineral $\mathrm{N}$ fertilizers play in this respect and what their position is, relative to organic fertilizers.

\section{Drivers}

The world as a whole is in need of more food, not just because 870 million people are still suffering from malnutrition [7], but also because the world population is expected to grow from today's 7 billion people to 9 billion in the year 2050. Moreover, the dietary preferences of people are gradually moving towards more meat and dairy products (Figure 1). Such an affluent diet requires much more crop land than what is needed for a diet without ingredients sourced from livestock production [8]. The Food and Agricultural Organization therefore estimates that agricultural production needs to increase by $60 \%$ in 2030-2050 in comparison to production levels in 2005-2007 [7]. In theory this demand can be met by converting more wilderness into agricultural land whilst using the same amounts of inputs per hectare including mineral $\mathrm{N}$ fertilizer, or by increasing yields on the existing area of agriculture land through increased inputs, or by increasing yields on the existing area of agricultural land whilst utilizing the same inputs more efficiently. The global amount of suitable agricultural land is hardly changing, however, implying that the available area per capita is becoming less and less (Figure 2). Global warming may further reduce the amount of suitable agricultural land although losses may partly be compensated by gains at greater latitudes [9]. The more or less fixed amount of agricultural land implies that continuous efforts to increase crop yields per unit land appear the only way forward [5]. For the world as a whole this has gone hand in hand with an increase of $\mathrm{N}$ fertilizer inputs per hectare and commensurate losses of $\mathrm{N}$ to air and water. From a theoretical point of view one could reason that wilderness can be saved or even restored by increasing crop yields per hectare and by, thus, reducing land consumption. From a historical perspective, however, it appears that gains in yields per unit land have not been used to save the area under wilderness, but rather to expand the human population and facilitate a more luxurious diet. Technologies, including the industrial synthesis of mineral fertilizer $\mathrm{N}$, evidently allowed mankind to withdraw himself from the natural negative feedback between population size and available food per capita [10]. There is a growing awareness that the product of population size and per capita demands has, as yet, a large negative impact on the environmental quality of the planet and the depletion rate of resources such as fresh water, fossil energy and rock-P [6].

However, now that the "spirit is out of the bottle" we cannot simply go back to the pre-industrial era as that would literally affect the life of billions [4] [11]. The real challenge therefore is to increase food production without a proportional increase of the area under agriculture or the input of agro-chemicals or, in other words: "how to produce more with less?" [5]. 

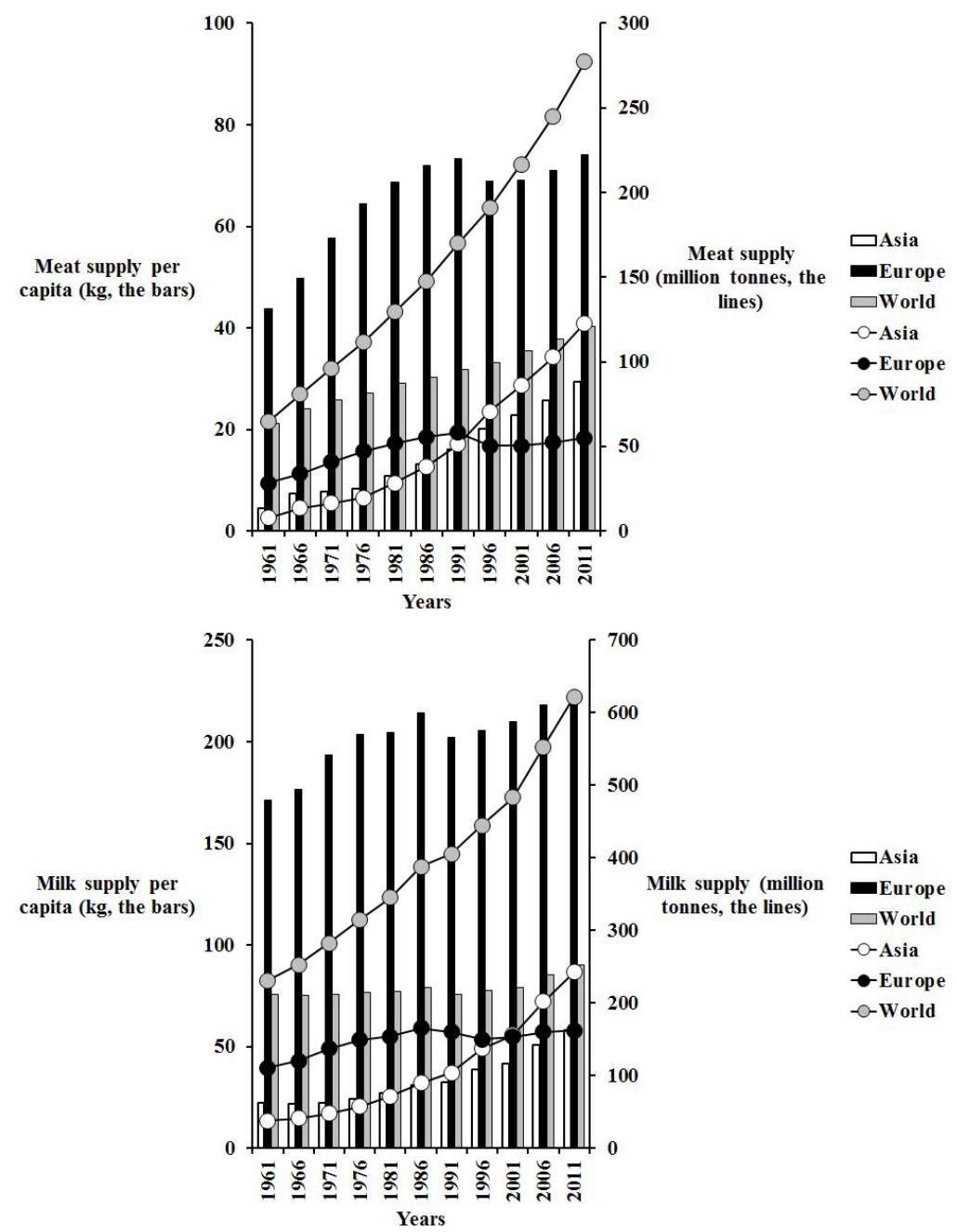

Figure 1. Historical development of meat supply (top) and milk supply (bottom) in developed and developing regions and in the world as a whole (source: FAOSTAT, 2014).

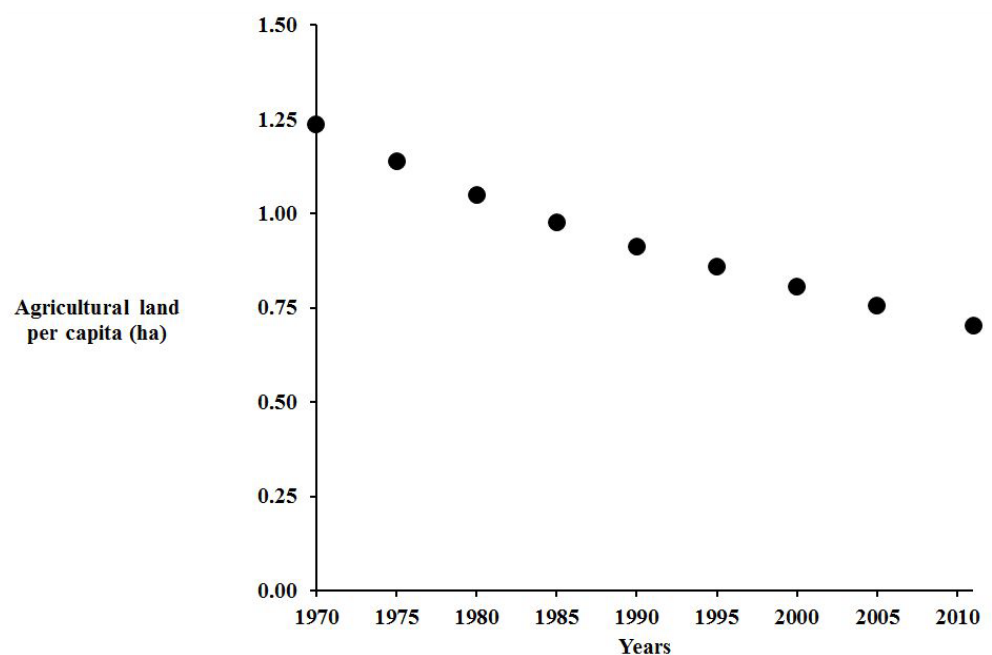

Figure 2. Historical development of available hectares of agricultural area per person (source: FAOSTAT, 2014). 


\section{Inevitable Losses}

\subsection{Per Hectare and per Unit Produce}

Nutrients, among which reactive $\mathrm{N}$ and phosphorus $(\mathrm{P})$ are scarce under natural conditions. In the course of the evolution plants have hence been challenged to utilize these nutrients efficiently. Agricultural crops share this ability but are just as much unable as wild species to fully recover nutrients, $\mathrm{N}$ in particular. Plants are simply unable to take up all the $\mathrm{N}$ that is made available to them, even at low levels of supply. The reason behind this is the notorious reactivity and mobility of N. Mobility is an appreciated characteristic because it allows plants to acquire $\mathrm{N}$ via the evaporation-driven mass flow towards and into the plant. Mobility also means, however, that $\mathrm{N}$ is easily lost to the wider environment. Losses to the air occur in the form of ammonia- $\mathrm{N}\left(\mathrm{NH}_{3}\right)$, nitrous oxide $\left(\mathrm{N}_{2} \mathrm{O}\right.$, “laughing gas") and elementary $\mathrm{N}\left(\mathrm{N}_{2}\right)$. Losses to water predominantly take place in the form of nitrate $\left(\mathrm{NO}_{3}\right)$. The supply of plant available $\mathrm{N}$, mainly nitrate, is inevitably exposed to leaching because fields in agricultural use are insufficiently larded with active roots at any moment and place. Besides, precipitation exceeds the evapotranspiration of soils and crops in many parts of the world (e.g. during winter in temperate regions and the rainy season in the tropics) and this results in a downward movement of water together with mobile elements such as nitrate-N. A natural, mixed vegetation compensates for this loss by the presence of, inter alia, legumes which are able to convert atmospheric elementary $\mathrm{N}_{2}$ into reactive $\mathrm{N}$, whereas a farmer generally makes up for lost $\mathrm{N}$ by applying mineral or organic $\mathrm{N}$ fertilizers. Applications of $\mathrm{N}$ should hence not only be directed at the compensation of the $\mathrm{N}$ exported with harvests, but also at compensation of these inevitable losses. Without compensation of both types of output, soil fertility and productivity cannot be maintained.

About half of the global arable land is devoted to growing cereals (mainly wheat, rice and maize). The absolute area nor the share of it have hardly changed between the 1960's and the beginning of the present century. Yields per hectare, however, increased by a factor 2.5 during this period (Figure 3). Of course, mineral fertilizer $\mathrm{N}$ is and has not been uniquely applied to cereals. However, assuming that the allocation of $\mathrm{N}$ to crop types has not changed, application rates per hectare of cereals have 7-folded in the course of these 40 - 50 years, suggesting that the recovery of applied $\mathrm{N}$ in harvests has dramatically dropped. By multiplying grain yields and typical cereal-type specific $\mathbf{N}$ concentrations [12] [13], one can calculate how much $\mathrm{N}$ is annually harvested. Even if one assumes that all the mineral fertilizer $\mathrm{N}$ is applied to cereal land (what is not very likely), the $\mathrm{N}$ recovery in the 60 s and early 70 s of the former century was well over $100 \%$ and that cannot be realistic. This high apparent recovery of fertilizer $\mathrm{N}$ implies that cereals must have relied at least partly on alternative sources of $\mathrm{N}$ such as ploughed in legumes or (residual effects of) manures (of which the production was probably also sustained by livestock feeding on legumes). If $\mathrm{N}$ recoveries are related to the sum of both types of "new" $\mathrm{N}$ (i.e. fertilizer $\mathrm{N}$ and estimated biologically fixed $\mathrm{N}$, following [14]), the apparent drop in $\mathrm{N}$ recovery of "applied" $\mathrm{N}$ would still be there but limited to a decrease from slightly more than $70 \%$ in 1960 to less than $60 \%$ in more recent times (Figure 4). Whatever the exact numbers, the use efficiency of $\mathrm{N}$ appears to have gradually decreased. Losses of $\mathrm{N}$ per unit land and unit produce therefore appear to have increased [5].

\subsection{Globally}

The close relationship between the production of mineral fertilizer $\mathrm{N}$ and the population growth (Figure 5) makes is plausible to assume that indeed mineral fertilizer was one of the dominating factors allowing the global population to double [1]. In his study on $\mathrm{N}_{2} \mathrm{O}$ emissions Davidson [14] presented time series (1860-2005) of both sources of "new" $\mathrm{N}$, i.e. of mineral fertilizer $\mathrm{N}$ and of biologically fixed $\mathrm{N}$, showing that both increased and that the inputs of mineral fertilizer $\mathrm{N}$ started to exceed the estimated amounts of biologically fixed $\mathrm{N}$ around 1970. The present global sum of both $\mathrm{N}$ sources measures slightly more than $120 \mathrm{Tg}$. Davidson [14] also included a time series of available manure $\mathrm{N}$, indicating that the total amount has increased to over $140 \mathrm{Tg} \mathrm{N}$. It is, however, difficult to understand how one can produce more manure $N$ than "new" N (140 > 120), unless there are substantial annual additions of $\mathrm{N}$ via $\mathrm{N}$ inputs to the livestock sector from grazing of (legume-supported) range land, depletion of soil N-pools, atmospheric $\mathrm{N}$ deposition or a considerable (but unlikely) recycling of sewage $\mathrm{N}$ to crop land (Figure 6). Oenema \& Tamminga [15] emphasized that the estimates of various authors of today's global manure $\mathrm{N}$ production varied by a factor 2, confirming how difficult it apparently is to link reliable $\mathrm{N}$ excretion rates to the livestock numbers. We therefore decided to adopt the average manure- $\mathrm{N}$ production number presented in [15] and scale the time series of [14] accordingly. 


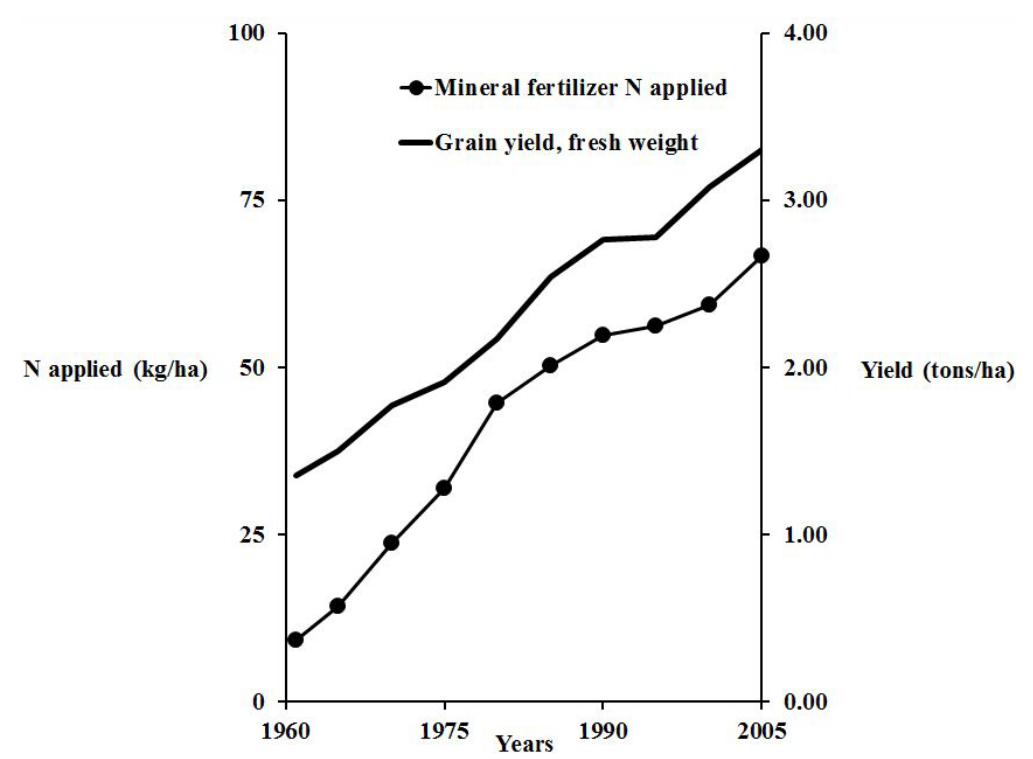

Figure 3. Historical development of grain yields (area weighted average, kg per hectare) and mineral fertilizer $\mathrm{N}$ application rate $\mathrm{N}$ (assuming application on cereal land only, kg per hectare) (source: FAOSTAT, 2014).

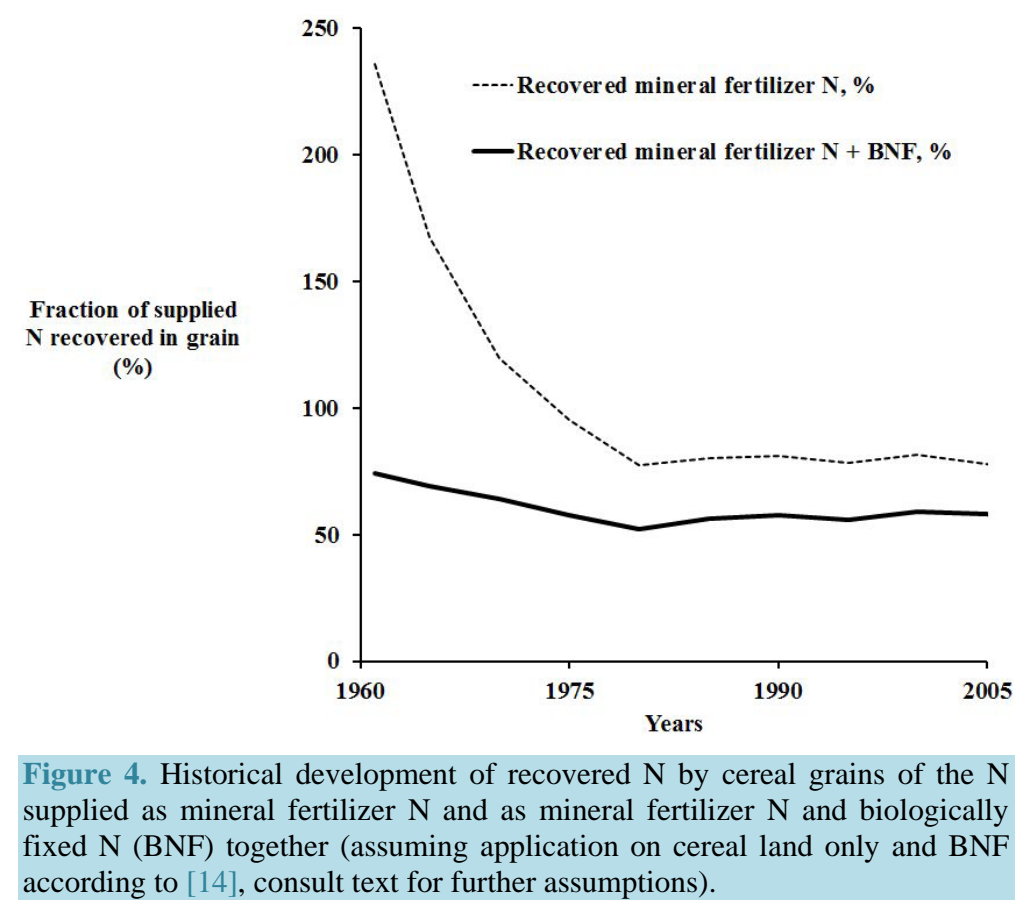

If one subsequently divides the global manure $\mathrm{N}$ production by the global population (regardless whether this manure $\mathrm{N}$ production is adjusted or not), it appears that the manure $\mathrm{N}$ production per capita has hardly changed over time, despite the evident increase of meat and dairy consumption per capita. This is another indication of the difficulty of making reliable estimates of the time course of $\mathrm{N}$ excretion by livestock. Note that the global sewage production (for which [14] implicitly assumed the $\mathrm{N}$ excretion per person to have risen from around 3.7 $\mathrm{kg}$ per year in the 19th century to $4.5 \mathrm{~kg}$ in recent years, reflecting the greater protein intake) represents an amount equivalent to circa only $25 \%$ of the "new" $\mathrm{N}$, suggesting that three quarters of the input of "new" $\mathrm{N}$ is lost before it even enters the human body. From this it is evident that the world is increasingly filled with reactive $\mathrm{N}$ to the detriment of the environment. 


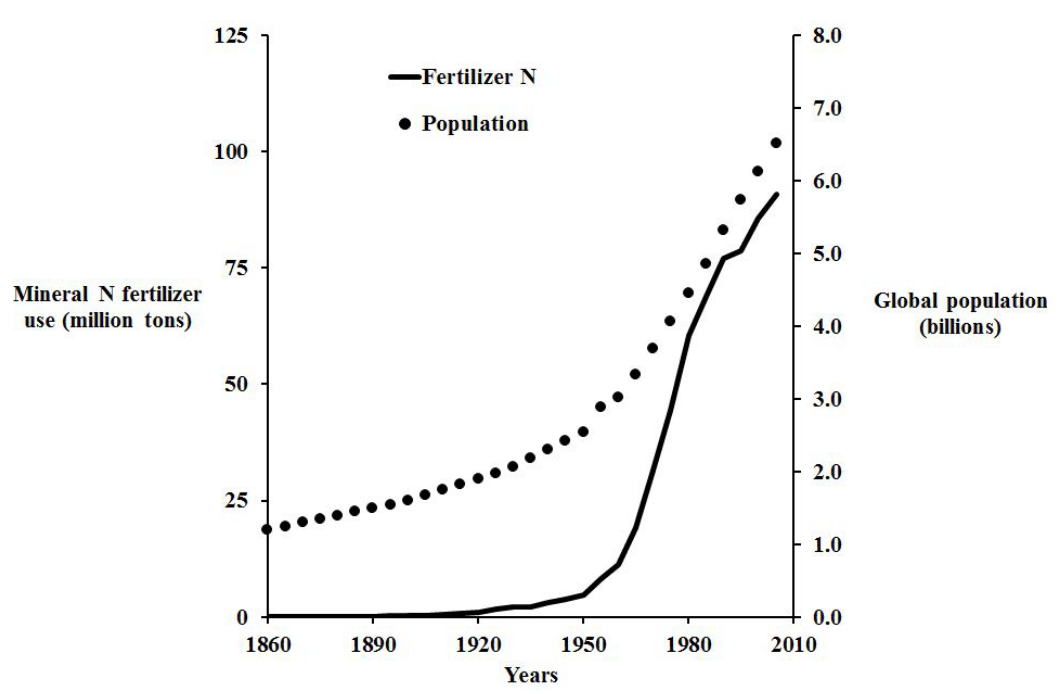

Figure 5. Historical development of mineral fertilizer N production (source: International Fertilizer Industry Association-IFA) and human population (source: FAOSTAT, 2014).

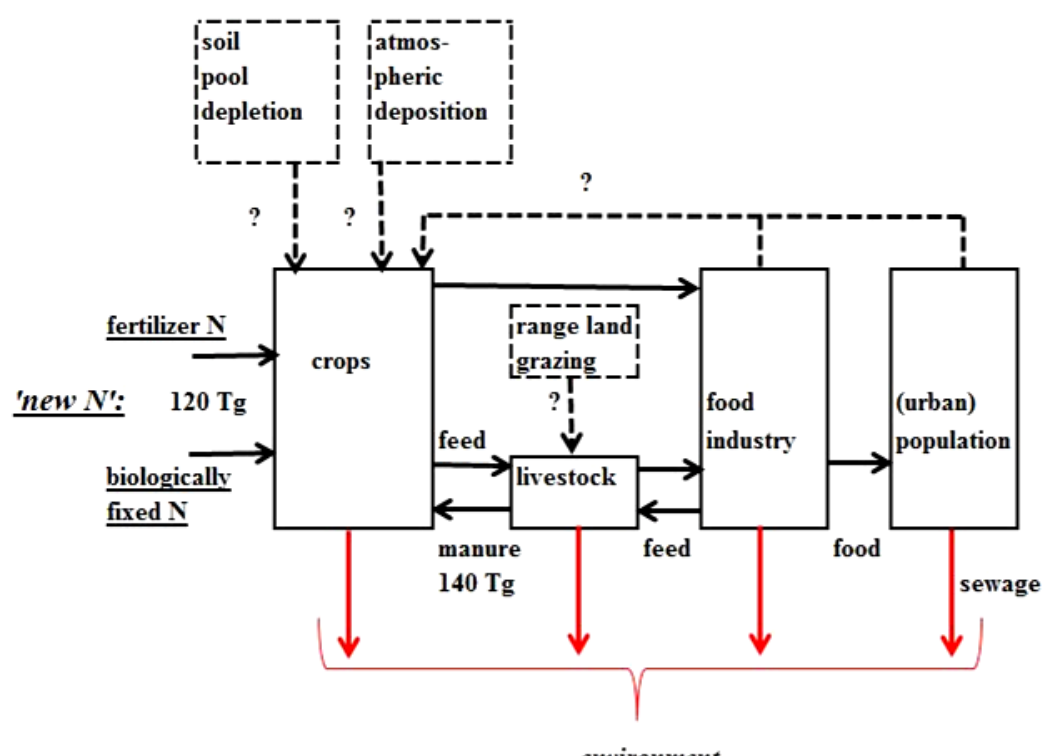

Figure 6. Theoretical flow diagram showing from what additional sources "new" $\mathrm{N}$ must originate (their exact magnitudes being unknown as indicated by "?”) being to sustain the alleged production of $140 \mathrm{Tg}$ of manure- $\mathrm{N}$ according to [14].

\section{Principle Nitrogen Deficiency}

The appearance of the food on our plates generally differs drastically from what crops look like. This is due to the fact that crops undergo processing via animals, industries and kitchens. All kind of by-products are generated along this pathway from field to plate: crop residues, manures, sludges, ashes, kitchen wastes, composts, and so on. Ideally, these by-products should be recycled, if alone because they contain compounds originating from finite sources such as rock P. By-products also deserve recycling because they contain valuable organic matter and micro-nutrients, some of them becoming scarce and yield limiting [16]. Moreover, if these by-products would not be re-used, their discard will sooner or later lead to local pollution of the environment. From a crop demand perspective, most of these products contain too little $\mathrm{N}$ per kilogram $\mathrm{P}$ [17], in particular because only a fraction of the $\mathrm{N}$ in by-products (the so-called $\mathrm{N}$ fertilizer replacement value "NFRV") is plant-available and 
because slightly more $\mathrm{N}$ should be applied than what is eventually taken up, due to inevitable losses. The reason for this relatively low $\mathrm{N}$ to $\mathrm{P}$ ratio in by-products is that $\mathrm{N}$ is easily lost during its course via animals, manure, soil, crops and, again, animals, or via additional loops including industries, retail and private households (Figure 7). The inherent tendency of food production systems to lose $\mathrm{N}$, implies that farms trying to fully cover their $\mathrm{N}$ requirements with just by-products are bound to accumulate $\mathrm{P}$ in their soils as they are applying more $\mathrm{P}$ than what is taken up by their crops. Conversely, farms intending to avoid $\mathrm{P}$ accumulation fall short of $\mathrm{N}$ in almost every case. Without $\mathrm{N}$ supplementations, more land needs to be reclaimed to produce the same volume of food. Our ancestors solved this $\mathrm{N}$ deficiency by regularly reclaiming pieces of wilderness ("shifting cultivation") in which $\mathrm{N}$ from natural sources (lightning, fires, biological $\mathrm{N}$ fixation) had accumulated or by growing legumes (e.g. "clovers") in between food crops and by growing grass-legume mixtures instead of pure stands of grass. Unlike most other crops, legumes are able to link the ubiquitously present atmospheric $\mathrm{N}_{\left(\mathrm{N}_{2}\right)}$ to carbohydrates $\left(\mathrm{CH}_{2} \mathrm{O}\right)$ produced by their photosynthesis, resulting in proteins and nucleic acids. Up to several hundred kilograms of $\mathrm{N}$ per hectare per year can be fixed by perennial legumes (e.g. [18]). Once ploughed-down as green manure or converted into manure by animals feeding on these legumes, these proteins and nucleic acids supply mineral $\mathrm{N}$ to other crops in the form of ammonium-N. In free draining soils this ammonium-N will be quickly converted by soil micro-organisms into nitrate-N. Ammonium- $\mathrm{N}$ and nitrate- $\mathrm{N}$ are the forms of $\mathrm{N}$ that can be taken up by roots, including the roots of crop plants. In the beginning of the 20th century the chemical industry managed to mimic what legumes have been doing for ages. In this so-called Haber-Bosch process atmospheric N is linked to hydrogen $(\mathrm{H})$ under high pressure and temperature to form ammonia- $\mathrm{N}$. The required energy and hydrogen $(\mathrm{H})$ atoms are generally derived from fossil fuels, but may as well be provided directly by solar energy and $\mathrm{H}$ from electric hydrolysis to mimic the biological fixation even more. Industrial $\mathrm{N}$ fixation and reliance on renewable energy are thus not per se conflicting. For the time being, however, it is energetically much more efficient to produce $\mathrm{H}$ from natural gas than from hydrolysis [19]. These industrial $\mathrm{N}$ fertilizers are by now the dominant source of $\mathrm{N}$ in agriculture.

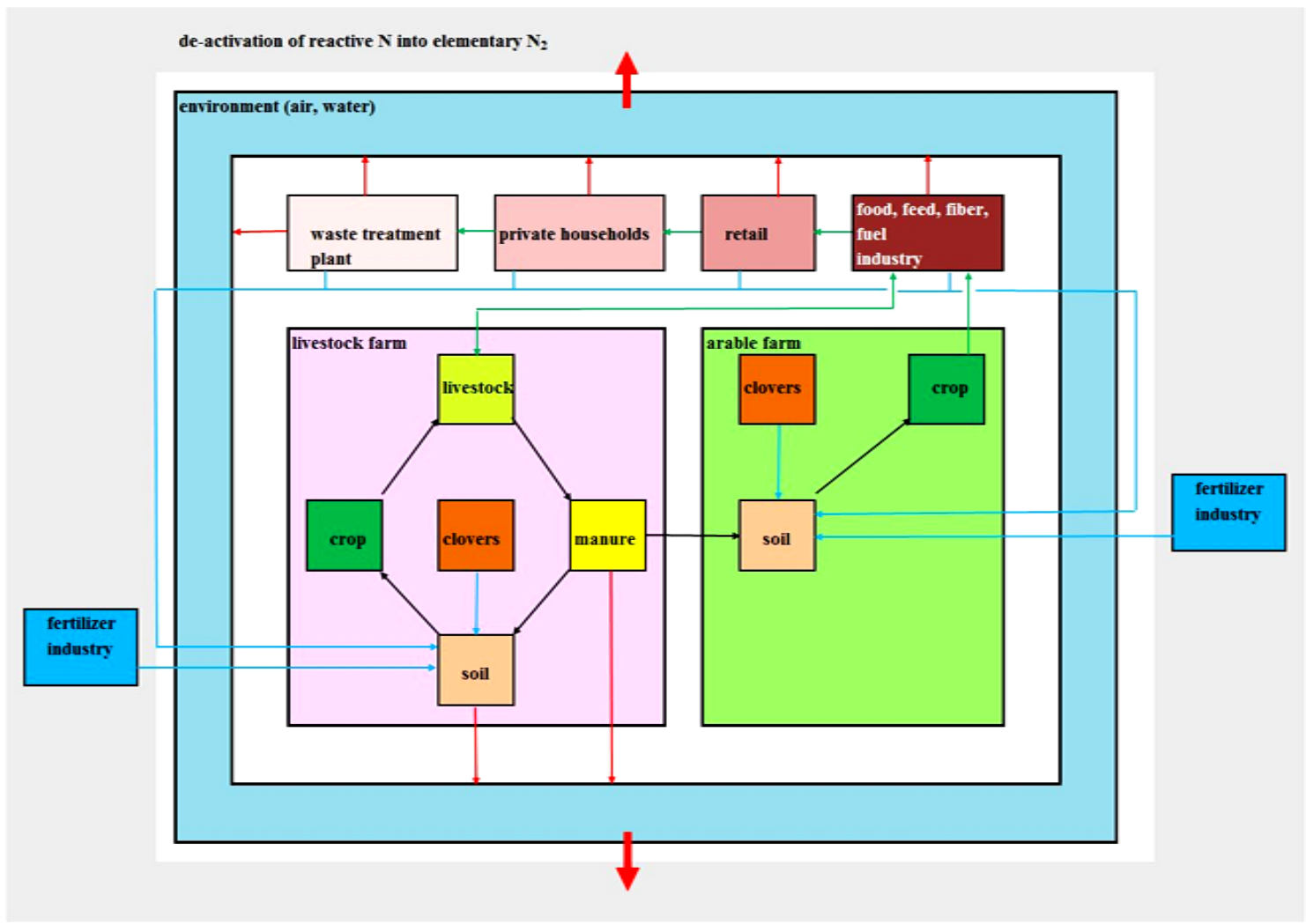

Figure 7. Diagram of an imaginary food production system consisting of production, processing and consumption compartments each inevitably losing $\mathrm{N}$ (red arrows), and thus requiring replenishment via waste recycling and synthesis of "new" reactive $\mathrm{N}$ (blue arrows). 


\section{Biological Nitrogen Fixation}

The $\mathrm{N}$ fertilizer industry is using solar energy that has been captured in the past ("fossil energy"), whereas legumes use the current solar energy. As a result of that, legumes consume land because one cannot use solar energy to fix $\mathrm{N}$ (more precisely: allocate photosynthetates to the $\mathrm{N}$-fixing bacteria living in symbiosis with legumes) without affecting the amount of solar energy that is left over for the production of food, feed, fiber and biofuel. In addition to land, legumes also demand other inputs of which the availability can be limited such as water. As far as the consumption of land is concerned, it must be noted that land consumption per unit $\mathrm{N}$ that is effectively available for crops that are deemed to benefit from these green manures, is even higher than indicated by the $\mathrm{N}$ fixation per hectare, as the $\mathrm{N}$ fertilizer replacement value of ploughed-in legumes will be less than $100 \%$, just as that of any other organic source of $\mathrm{N}$ (consult next paragraph for details). If one assumes that one hectare of legume land fixes $100-300 \mathrm{~kg} \mathrm{~N}$ per year [18] and that three quarters of this amount can effectively converted into mineral $\mathrm{N}$ equivalents for subsequent crops [20], the current global application rate of mineral fertilizer N (22 kg N per ha) would equate with an additional arable land claim of almost 30\% - 100\%. Schröder \& Sörensen [21] presented a simple model N directed at calculating the demand for land in function of choices with respect to the sources of $\mathrm{N}$ (mineral fertilizer $\mathrm{N}$, urban residues, legumes), dietary aspirations, and attainable yield levels. Their model simulations indicate that an intensive strategy (ambitious yield levels, mineral fertilizer $\mathrm{N}$ ) needs half the amount of land of an extensive strategy (modest yield levels, biologically fixed $\mathrm{N}$ in addition to the recycling of urban residues). This outcome mirrors the combined effects of lower food yields per hectare resulting from extensification and the dilutions of these yields per hectare with the additional hectares needed for growing legumes. The loss of $\mathrm{N}$ per hectare of the intensive system is higher but the global $\mathrm{N}$ loss (i.e. the product of the loss per hectare and the number of hectares needed) of both strategies are quite similar. However, an affluent diet produced according to the intensive strategy needs as much land as a moderate diet produced according to the extensive strategy, whilst losing around twice as much $\mathrm{N}$ per hectare. It shows that $\mathrm{N}$ losses are just as much determined by decisions on what we eat ourselves than by decisions on how we feed our crops.

\section{Organic Fertilizers}

The compensation of locally depleted $\mathrm{N}$ can be carried out via either biologically fixed $\mathrm{N}$, via the application of "synthetic" mineral fertilizer $\mathrm{N}$ or via the application of $\mathrm{N}$ containing by-products among which manures. Note that the latter were once produced on the basis of biologically fixed $\mathrm{N}$ or mineral $\mathrm{N}$ fertilizer as well. The form in which $\mathrm{N}$ is offered strongly determines to what extent $\mathrm{N}$ can be utilized by crops. The $\mathrm{N}$ compounds in $\mathrm{N}$ containing by-products are at least partly organically bound. This implies that that $\mathrm{N}$ cannot be directly assimilated by plants. This applies, for example, to the $\mathrm{N}$ in livestock manures, in composts, in green manures and in residues from preceding crops. These forms of $\mathrm{N}$ need to be mineralized before they can be taken up by roots. However, the temporal match between mineralization and crop demand is not always perfect and that is another reason why losses of $\mathrm{N}$ may occur. The ability of organic fertilizers to provide $\mathrm{N}$ is, however, not just reduced by this untimely mineralization. The inherent composition of organic $\mathrm{N}$ fertilizers can also stimulate other loss processes such as denitrification [22] [23] and volatilization of ammonia [24]. This limited availability of $\mathrm{N}$ from organic fertilizers can be expressed in so-called $\mathrm{N}$ fertilizer replacement values (NFRVs). The NFRV of an organic fertilizer is defined as the kg's $\mathrm{N}$ per $100 \mathrm{~kg}$ total $\mathrm{N}$ applied having the same yield effect as mineral fertilizer $\mathrm{N}$ [25].

The NFRV of organic fertilizers is generally not only less than that of mineral fertilizer but also more variable. The eventual NFRV depends on the ratio of mineral $\mathrm{N}$ and organically bound $\mathrm{N}$, on the extent to which the fertilizer is effectively incorporated into the soil (determining volatilization losses of ammonia- $\mathrm{N}$ [21] [24]), on the length of the growing season (determining the extent to which mineralization patterns of organic $\mathrm{N}$ lag behind the crop uptake patterns), on the time of application (as heavier soil types can make it impossible to apply some types of organic fertilizers at the start of the growing season without damaging soils or crops), on weather and soil conditions, and on the manuring history. The manuring history determines to which extent farmers should factor-in the accumulated residual effects of applications in preceding years [26]. In addition to these relatively low and variable NFRVs, is it noteworthy to say that the nutrients in organic fertilizers are generally strongly diluted, whereas nutrients in industrially synthesized $\mathrm{N}$ fertilizers are up to hundreds times as concentrated as organic fertilizers, making their handling (storage, transport, positioning) relatively easy. Besides, organic ferti- 
lizers generally represent mixtures of nutrients in more or less fixed ratios, whereas the application of industrially synthesized fertilizers can be tailored to the specific requirements of soils, climates and crops.

\section{Recycling within Limits}

Given their greater plant-availability, mineral fertilizers generally result in a better $\mathrm{N}$ use efficiency (NUE) than by-products. However, it is short-sighted to compare the use efficiency of these two $\mathrm{N}$ sources, because byproducts simply do need re-cycling, regardless the lower plant-availability of $\mathrm{N}$. Growers turning up their noses for these by-products in order to maximize their NUE, leave the recycling to someone else and are thus basically increasing their use efficiency at the expense of someone else's. From the perspective of the society as a whole, it is not the NUE of subsystems (e.g. that of a livestock-less grower of crops or that of a land-less livestock producer) that matters, but the $\mathrm{N}$ use efficiency of food production as a whole. From a similar perspective it is silly to state that specialized farms (stockless arable or landless livestock as opposed to mixed farming systems or systems including "upstream processing”) are "more efficient”, as their seemingly better efficiency is a numerical artifact [27].

The production of crops, the processing of these crops via livestock, industries and markets, and the eventual consumption in our homes, have unfortunately become spatially disrupted. This "globalization" complicates recycling, if alone because it is simply cheaper to compensate with mineral fertilizers. Consequently, by-products are not always efficiently collected and stored. The recycling potential is also compromised whenever by-products become contaminated with medicine residues, pathogens and heavy metals, which may more easily happen in an "anonymous" collective urban environment. By-products may contain considerable amounts of, for instance, copper and zinc. Unlimited use of these types of by-products can eventually have a negative effect on the productivity of soils and human health [28]. Besides, the valuable constituents in by-products are often diluted by the addition of water from flushing and water associated with human and livestock excretions. Dilution makes the recovery or transport of nutrients in by-products expensive, compared to the concentrated industrially synthesized fertilizers. Beyond a certain distance the transport of "water" simply becomes more energy consuming than the synthesis of fertilizers. The position of the "break-even point" depends on the nutrient concentrations in the by-product, the energy consumption needed for its transport and the energy needed for the synthesis of an equivalent amount of fertilizer N. It has been estimated that the transport of, for example, common pig slurry becomes questionable beyond distances of around 100 kilometers [29]. Trade-offs such as these can sooner or later ask for rethinking the spatial organization of societies [10].

\section{Manure Treatment}

There is no principle need to meet the local crop demand everywhere with the same mix of $\mathrm{N}$ derived from by-products and $\mathrm{N}$ derived from "new" N, including mineral $\mathrm{N}$ fertilizers, as long the use of by-products has no unwanted side effects such as $\mathrm{P}$ accumulation. Self-evidently, high relative shares of $\mathrm{N}$ from (treated) by-products in one place (field, farm, region, country, ...) go hand in hand with a relatively high share of mineral fertilizer $\mathrm{N}$ or legumes in another place. Regional surpluses of manure stem from situations in which many more animals are kept than the numbers that can be sustained with just the local feed production i.e. without imports of feed. As manures generally contain more $P$ per unit plant-available $N$ than needed by crops [17], it is usually $\mathrm{P}$ that first limits the potential to apply manures without the accumulation of $\mathrm{P}$ in soils. Accumulation can only be avoided by a more balanced distribution of farms, industries and people [10] or by exporting the surplus of nutrients to the soils where they were once taken up from. Moving manure over great distances is energy demanding, as indicated, particularly in case of slurries. Dewatering of slurries can make their transport more energy-efficient. Dewatering can be carried out by a process that separates the slurry into a solid fraction and a watery liquid fraction. The solid fraction is usually relatively poor in water soluble $\mathrm{N}$ and rich in $\mathrm{P}$ and organically bound N, whereas the reverse holds for the liquid fraction [30] [31]. Separation is deemed to reduce the overall energy consumption, despite the energy consumption of the separation process itself. The idea behind it is to keep the watery liquid fraction, relatively rich in $\mathrm{N}$, within the region where manures are produced. In that region there will generally still be a need for $\mathrm{N}$, after all. As a consequence, only the dewatered solid fraction needs to be transported to distant regions. Note, that the solid fraction contains less $\mathrm{N}$ per $\mathrm{kg} \mathrm{P}$ than the original slurry, meaning that savings on $\mathrm{N}$ in the one region will at least partly be countered by additional expenses on $\mathrm{N}$ in the other region [32]. 


\section{Health Issues}

As explained in the preceding paragraphs, agriculture must not turn up its nose for manure and other organic by-products. It has also been explained that agriculture cannot be sustainable without inputs of "new" $\mathrm{N}$ of which mineral fertilizer $\mathrm{N}$ is an efficient form. Organic farming rejects the use mineral fertilizer $\mathrm{N}$ and opts for biological $\mathrm{N}$ fixation instead. In addition to that, organic farming denounces the use of synthetic pesticides. Extensive research has thus far not provided convincing evidence that abstinence from mineral fertilizer and pesticides leads to healthier food, at least not in the developed world [33]-[35]. In as far as nitrate is a problem for the quality of food, it is the application rate and not the source that determines the composition of food [36]. Food quality is therefore no reason to reconsider the use of mineral fertilizer $\mathrm{N}$.

Health issues are not only raised in relation to human health but also in relation to soil health. The term soil health refers to the ability of a soil to host and support organisms that are beneficial for the yield and the quality of crops. It is closely related to the term soil quality. Soil quality, however, usually has a slightly broader scope as it pertains to the potential of a soil to deliver ecosystem services, among which the production of crops. The health and quality of a soil depends on its physical, chemical and biological characteristics. Organic matter plays a crucial role in soil health and soil quality: as a building block for the physical structure of soils, as a matrix facilitating the temporary storage of nutrients and the buffering of acidity, and last but not least as food for soil organisms. Crop residues are the source of this soil organic matter. Crop residues provide organic matter either directly in the form of non-harvested plant parts or indirectly in the form of by-products becoming available during the processing of crops. Soil organic matter contents can only be maintained via regular inputs of new material as soil organisms consume organic matter.

Mineral fertilizers, $\mathrm{N}$ containing fertilizers in particular, have been criticized because of their alleged negative impact on soil health and quality. First, there is the general observation of positive relationships between the presence of soil life, organic matter contents, mineralization of $\mathrm{N}$ and the resultant crop yields. This observation has been interpreted as an indication that yields are positively related to soil life and soil life thus needs to be cherished and nourished. However, phenomena appear to be twisted around: the enhanced mineralization is not the merit of promoted soil life but merely a logical consequence of greater presence of built-up organic matter. Extended soil life is mainly an expression of this greater supply of food. In line with this, research has indicated that the recovery of both organic $\mathrm{N}$ and mineral $\mathrm{N}$ by crops is not significantly affected by the abundance of soil life [37] [38]. Although organic matter and soil organisms are indispensable to sustain soil quality in general and soil fertility in particular, there is apparently no need to supply the required $\mathrm{N}$ supplements in an organic form (i.e. via $\mathrm{N}$ fixing legumes or via solid manures from animals fed on these legumes) rather than in the form of mineral fertilizer $\mathrm{N}$.

Kotschi [39] recently restarted the debate on the effects of mineral fertilizer $\mathrm{N}$ on soil quality and long term soil fertility. He is obviously right in saying that $\mathrm{N}$ applications are ineffective wherever lack of $\mathrm{P}$, micro-nutrients, or organic matter is the true cause of low yields. However, Kotchi [39] also stated that " $\mathrm{N}$ is like a drug ruining the body" and that "mineral $\mathrm{N}$ fertilizers pose a threat to food security rather than improving it". His explicit conclusion that mineral fertilizer $\mathrm{N}$ even reduces organic matter contents of soils via enhanced decomposition is not at all underpinned. Kotschi [39] based his statement on experiments [40] [41]. However, he seems to have ignored the critical comments on these experiments by Reid [42] and Powlson et al. [43]. They pointed at the fact that the treatment with the high mineral fertilizer $\mathrm{N}$ input on which [40] and [41] based their conclusions regarding stimulated decomposition, was clearly confounded with high initial organic matter contents resulting from previous treatments in the experiments. These higher initial contents are a much more plausible explanation for the observed changes of organic matter contents, than the $\mathrm{N}$ input levels themselves. Reid [42] and Powlson et al. [43] also indicated that their own analysis of the literature rather points at a positive relationship between the use of fertilizers and organic matter contents due to increased inputs of crop residues. At the same time it seems fair to say that the positive effect of $\mathrm{N}$ inputs to organic matter contents should not be overestimated. Based on two long-term trials Russell et al. [44] demonstrated that the positive effect of $\mathrm{N}$ fertilizer use on residue production (and hence carbon inputs into soils) can in some rotations be partly countered by an increased decay rate resulting from narrowed carbon to $\mathrm{N}$ ratios. Apparently, too little $\mathrm{N}$ has a negative effect on the amounts of crop residues returning to soils and, hence, organic matter contents, whereas ample or too much $\mathrm{N}$ has not any benefit. 


\section{How to Minimize Losses?}

The preceding paragraphs have argued that global $\mathrm{N}$ losses will not become any smaller by refraining from organic $\mathrm{N}$ sources or by substituting biologically fixed $\mathrm{N}$ for industrially fixed $\mathrm{N}$. A blunt reduction of $\mathrm{N}$ rates will neither contribute to a cleaner global environment, as long as the agricultural industry as a whole intends to provide a similar diet to a similar number of people. If extensification would also include refrainment from other yield promoting measures (irrigation, drainage, pest control, use of improved genotypes, etc.), extensification can even become contra-productive in terms of $\mathrm{N}$ use efficiency.

The best way forward hence seems to be a reduction of mineral fertilizer $\mathrm{N}$ rates to what a crop really needs, whilst applying the best available techniques for the recycling of $\mathrm{N}$ containing by-products and what is needed in view of the true need of a crop. Again, the devil is in the detail because it is not easy to assess what the "true need of a crop" exactly is. Common sense indicates that the use efficiency of $\mathrm{N}$ is served by appropriate choices concerning the form, timing and positioning of fertilizers, taking the interactions of these three aspects into account. Obviously, use efficiency is also strongly dependent on applying the correct rate of $\mathrm{N}$ fertilizer. Decisions on these rates can be improved by integrating information on temporal and spatial variability of (patches within) fields [45]-[47], assuring "to stay away from the flat end of the $\mathrm{N}$ response curve". The general feeling is that this flat end can be identified quite precisely in the case of small grains and that there is therefore no principle conflict between what a farmer should apply from an economical point of view and from an environmental point of view (e.g. [48]). However, in crops such as maize the marginal utilization of $\mathrm{N}$ tends to decrease before the economical optimum $\mathrm{N}$ rate is attained (e.g. [49]). Under those circumstances there is a dilemma between what is judicious from an environmental point of view and what can be economically justified. Special attention is then needed to determine the $\mathrm{N}$ rate that minimizes global $\mathrm{N}$ losses (hectares times $\mathrm{N}$ loss per hectare) and land consumption.

\section{Concluding Remarks}

The shared ambition of societies all over the world is to produce more food, feed, fiber, biofuel and other biobased raw materials without a proportional increase of inputs such as nitrogen $(\mathrm{N})$ and land. It is evident that agriculture cannot become sustainable without regular inputs of "new" $\mathrm{N}$ in the form of fixed atmospheric $\mathrm{N}_{2}$. By-products, among which livestock manures, are an extremely valuable source of $\mathrm{N}$ deserving re-use but are not to be seen as such "new" $\mathrm{N}$, as opposed to the $\mathrm{N}_{2}$ fixed by legumes or the fertilizer industry. If the present use of mineral fertilizer $\mathrm{N}$ had to be replaced by $\mathrm{N}$ fixing legumes, up to twice as much arable land would be needed to grow these $\mathrm{N}$ fixers. This would lead to further reclamation of existing wilderness. Industrial $\mathrm{N}$ fixation hardly consumes scarce land but depletes fossil fuel reserves by using, as yet, around one cubic meter of natural gas per kilogram $\mathrm{N}$. Although there are no indications that judicious use of mineral fertilizer $\mathrm{N}$ has a detrimental effect on the quality of soils or food, there is an urgent need to reduce the environmental impact associated with the production and use of any source of $\mathrm{N}$, including mineral fertilizers.

\section{Acknowledgements}

Preparatory work for this paper was financially supported by OCI Nitrogen, Geleen, The Netherlands.

\section{References}

[1] Erisman, J.W., Van Grinsven, H., Grizzetti, B., Bouraoui, F., Powlson, D., Sutton, M.A., Bleeker, A. and Reis, S. (2011) The European Nitrogen Problem in a Global Perspective. In: Sutton, M.A., et al., Eds., The European Nitrogen Assessment, Cambridge University Press, Cambridge, 9-31. http://dx.doi.org/10.1017/CBO9780511976988.005

[2] Sutton, M.A., Howard, C.M., Erisman, J.W., Bealey, W.J., Billen, G., Bleeker, A., Bouwman, A.F., Grennfelt, P., Van Grinsven, H. and Grizzetti, B. (2011) The Challenge to Integrate Nitrogen Science and Policies: The European Nitrogen Assessment Approach. In: Sutton, M.A., et al., Eds., The European Nitrogen Assessment, Cambridge University Press, Cambridge, 82-96. http://dx.doi.org/10.1017/CBO9780511976988.008

[3] Skowronska, M. and Filipek, T. (2013) Life Cycle Assessment of Fertilizers: A Review. International Agrophysics, 28, 101-110.

[4] Smil, V. (2011) Nitrogen Cycle and World Food Production. World Agriculture, 2, 9-13.

[5] Tilman, D., Cassman, K.G., Matson, P.A., Naylor, R. and Polasky, S. (2002) Agricultural Sustainability and Intensive Production Practices. Nature, 418, 671-677. http://dx.doi.org/10.1038/nature01014 
[6] Rockström, J., Steffen, W., Noone, K., Persson, Å., Chapin, F.S., Lambin, E., Lenton, T.M., Scheffer, M., Folke, C., Schellnhuber, H., Nykvist, B., De Wit, C.A., Hughes, T., Van der Leeuw, S., Rodhe, H., Sörlin, S., Snyder, P.K., Costanza, R., Svedin, U., Falkenmark, M., Karlberg, L., Corell, R.W., Fabry, V.J., Hansen, J., Walker, B., Liverman, D., Richardson, K., Crutzen, P. and Foley, J. (2009) Planetary Boundaries: Exploring the Safe Operating Space for Humanity. Ecology and Society, 14, 32.

[7] FAO (2012) World Agriculture towards 2030/2050: The 2012 Revision. ESAE Working Paper No. 12-03. http://www.fao.org/economic/esa/esag/en/

[8] Gerbens-Leenes, P.W. and Nonhebel, S. (2002) Consumption Patterns and Their Effects on Land Required for Food. Ecological Economics, 42, 185-199. http://dx.doi.org/10.1016/S0921-8009(02)00049-6

[9] Oleson, J.E. and Bindi, M. (2002) Consequences of Climate Change for European Agricultural Productivity, Land Use and Policy. European Journal of Agronomy, 16, 239-262. http://dx.doi.org/10.1016/S1161-0301(02)00004-7

[10] Brown, A.D. (2003) Feed of Feedback. Agriculture, Population Dynamics and the State of the Planet. International Books, Utrecht.

[11] Smil, V. (2001) Enriching the Earth: Fritz Haber, Carl Bosch, and the Transformation of World Food Production. The MIT Press, Cambridge.

[12] Beukeboom, J.A. (1996) Default Values for Nutrient Book Keeping. Informatie en Kennis Centrum Landbouw, Ede.

[13] Van Duivenbooden, N., De Wit, C.T. and Van Keulen, H. (1996) Nitrogen, Phosphorus and Potassium Relations in Five Major Cereals Reviewed. Fertilizer Research, 44, 37-49. http://dx.doi.org/10.1007/BF00750691

[14] Davidson, E.A. (2009) The Contribution of Manure and Fertilizer Nitrogen to Atmospheric Nitrous Oxide since 1860. Nature Geoscience, 2, 659-662. http://dx.doi.org/10.1038/ngeo608

[15] Oenema, O. and Tamminga, S. (2005) Nitrogen in Global Animal Production and Management Options for Improving Nitrogen Use Efficiency. Science in China. Series C: Life Sciences, 48, 871-887.

[16] Moran, K. (2011) Role of Micronutrients in Maximizing Yields and in Biofortification of Food Crops. Proceedings 702, International Fertilizer Society, Leek, 28 p.

[17] Schröder, J.J. (2005) Manure as a Suitable Component of Precise Nitrogen Nutrition. Proceedings 574, International Fertiliser Society, York, $32 \mathrm{p}$.

[18] Herridge, D.F., Peoples, M.B. and Boddey, R.M. (2008) Global Inputs of Biological Nitrogen Fixation in Agricultural Systems. Plant and Soil, 311, 1-18. http://dx.doi.org/10.1007/s11104-008-9668-3

[19] Dawson, C.J. and Hilton, J. (2011) Fertiliser Availability in a Resource-Limited World: Production and Recycling of Nitrogen and Phosphorus. Food Policy, 36, 14-22. http://dx.doi.org/10.1016/j.foodpol.2010.11.012

[20] Schröder, J.J., Ten Holte, L. and Janssen, B.H. (1997) Non-Overwintering Cover Crops: A Significant Source of N. Netherlands Journal of Agricultural Science, 45, 231-248.

[21] Schröder, J.J. and Sörensen, P. (2011) The Role of Mineral Fertilizers in Optimising the Use Efficiency of Manure and Land. Proceedings 701, International Fertiliser Society, Leek, 20 p.

[22] De Klein, C.A.M., Van Logtestijn, R.S.P., Van der Meer, H.G. and Geurink, J.H. (1996) Nitrogen Loss from Cattle Slurry Injected into Grassland Soil with and without a Nitrification Inhibitor. Plant and Soil, 183, 161-170. http://dx.doi.org/10.1007/BF00011431

[23] Flessa, H. and Beese, F. (2000) Laboratory Estimates of Trace Gas Emissions Following Surface Application and Injection of Cattle Slurry. Journal of Environmental Quality, 29, 262-268. http://dx.doi.org/10.2134/jeq2000.00472425002900010033x

[24] Huijsmans, J. and Schils, R.L.M. (2009) Ammonia and Nitrous Oxide Emissions Following Field Application of Manure: State of the Art Measurement in the Netherlands. Proceedings 655, International Fertiliser Society, Leek, 37 p.

[25] Webb, J., Sörensen, P., Velthof, G., Amon, B., Pinto, M., Rodhe, L., Salomon, E., Hutchings, N., Burczyk, P. and Reid, J. (2013) An Assessment of the Variation of Manure Nitrogen Efficiency throughout Europe and an Appraisal of Means to Increase Manure-N Efficiency. Advances in Agronomy, 119, 371-442. http://dx.doi.org/10.1016/B978-0-12-407247-3.00007-X

[26] Schröder, J.J., Uenk, D. and Hilhorst, G.J. (2007) Long-Term Nitrogen Fertilizer Replacement Value of Cattle Manures Applied to Cut Grassland. Plant and Soil, 299, 83-99. http://dx.doi.org/10.1007/s11104-007-9365-7

[27] Schröder, J.J., Aarts, H.F.M., Ten Berge, H.F.M., Van Keulen, H. and Neeteson, J.J. (2003) An Evaluation of WholeFarm Nitrogen Balances and Related Indices for Efficient Nitrogen Use. European Journal of Agronomy, 20, 33-44. http://dx.doi.org/10.1016/S1161-0301(03)00070-4

[28] Wuana, A. and Okieimen, F.E. (2011) Heavy Metals in Contaminated Soils: A Review of Sources, Chemistry, Risks and Best Available Strategies for Remediation. ISRN Ecology, 2011, Article ID: 402647.

[29] Fealy, R. and Schröder, J.J. (2008) Assessment of Manure Transport Distances and Their Impact on Economic and En- 
ergy Cost. Proceedings 642, International Fertiliser Society, York, 28 p.

[30] Foged, H.L., Flotats, X., Blasi, A.B., Palatsi, J., Magri, A. and Schelde, K.M. (2011) Inventory of Manure Processing Activities in Europe. Technical Report No. I (ENV.B.1/ETU/2010/0007) to the European Commission, DirectorateGeneral Environment, 138 p.

[31] Hjorth, M., Christensen, K.V., Christensen, M.L. and Sommer, S.G. (2010) Solid Liquid Separation of Animal Slurry in Theory and Practice: A Review. Agronomy for Sustainable Development, 30, 153-180. http://dx.doi.org/10.1051/agro/2009010

[32] De Vries, J.W., Groenestein, C.M. and De Boer, I.J.M. (2012) Environmental Consequences of Processing Manure to Produce Mineral Fertilizer and Bio-Energy. Journal of Environmental Management, 102, 173-183. http://dx.doi.org/10.1016/j.jenvman.2012.02.032

[33] Dangour, A.D., Dodhia, S.K., Hayter, A., Allen, E., Lock, K. and Uauy, R. (2009) Nutritional Quality of Organic Foods: A Systematic Review. American Journal of Clinical Nutrition, 90, 680-685. http://dx.doi.org/10.3945/ajcn.2009.28041

[34] EUFIC (2013) Organic Food and Farming: Scientific Facts and Consumer Perceptions. EUFIC Review 10/2013. http://www.eufic.org/article/en/expid/Organic_food_and_farming_scientific_facts_and_consumer_perceptions/

[35] Smith-Spangler, C., Brandeau, M.L., Olkin, I. and Bravata, D.M. (2013) Are Organic Foods Safer or Healthier? Annals of Internal Medicine, 158, 297-300. http://dx.doi.org/10.7326/0003-4819-158-4-201302190-00019

[36] Addiscott, T.M., Whitmore, A.P. and Powlson, D.S. (1991) Farming, Fertilizers and the Environment. Oxford University Press, Oxford.

[37] Bosshard, C., Sørensen, P., Frossard, E., Dubois, D., Mäder, P., Nanzer, S. and Oberson, A. (2009) Nitrogen Use Efficiency of Animal Manure and Mineral Fertiliser Applied to Long-Term Organic and Conventional Cropping Systems. Nutrient Cycling in Agroecosystems, 83, 271-287. http://dx.doi.org/10.1007/s10705-008-9218-7

[38] Langmeier, M., Frossard, E., Kreuzer, M., Mäder, P., Dubois, D. and Oberson, A. (2002) Nitrogen Fertilizer Value of Cattle Manure Applied on Soils Originating from Organic and Conventional Farming Systems. Agronomie, 22, 789800. http://dx.doi.org/10.1051/agro:2002044

[39] Kotschi, J. (2013) A Soiled Reputation: Adverse Impacts of Mineral Fertilizers in Tropical Agriculture. Commissioned by World Wildlife Fund (Germany) to Heinrich Böll Stiftung, 58 p.

[40] Kahn, S.A., Mulvaney, R.L., Ellsworth, T.R. and Boast, C.W. (2007) The Myth of Nitrogen Fertilization for Soil Carbon Sequestration. Journal of Environmental Quality, 36, 1821-1832. http://dx.doi.org/10.2134/jeq2007.0099

[41] Mulvaney, R.L., Khan, S.A. and Ellsworth, T.R. (2009) Synthetic Nitrogen Fertilizers Deplete Soil Nitrogen: A Global Dilemma for Sustainable Cereal Production. Journal of Environmental Quality, 38, 2295-2314. http://dx.doi.org/10.2134/jeq2008.0527

[42] Reid, D.K. (2007) Comment on "The Myth of Nitrogen Fertilization for Soil Carbon Sequestration” by S.A. Kahn et al. in the Journal of Environmental Quality 36: 1821-1832. Journal of Environmental Quality, 37, 739-740. http://dx.doi.org/10.2134/jeq2008.0001le

[43] Powlson, D.S., Jenkinson, D.S., Johnston, A.E., Pouton, P.R., Glendining, M.J. and Goulding, K.W. (2010) Comments on "Synthetic Nitrogen Fertilizers Deplete Soil Nitrogen: A Global Dilemma for Sustainable Cereal Production," by R.L. Mulvaney, S.A. Khan, and T.R. Ellsworth in the Journal of Environmental Quality 2009 38: 2295-2314. Journal of Environmental Quality, 39, 749-752. http://dx.doi.org/10.2134/jeq2010.0001le

[44] Russell, A.E., Cambardella, C.A., Laird, D.A., Jaynes, D.B. and Meek, D.W. (2009) Nitrogen Fertilizer Effects on Soil Carbon Balances in Midwestern U.S. Agricultural Systems. Ecological Applications, 19, 1102-1113. http://dx.doi.org/10.1890/07-1919.1

[45] Sylvester-Bradley, R., Lord, E., Sparkes, D.L., Scott, R.K., Wiltshire, J.J.J. and Orson, J. (1999) An Analysis of the Potential of Precision Farming in Northern Europe. Soil Use and Management, 15, 1-8.

[46] Schröder, J.J., Neeteson, J.J., Oenema, O. and Struik, P.C. (2000) Does the Crop or the Soil Indicate How to Save Nitrogen in Maize Production? Field Crops Research, 62, 151-164. http://dx.doi.org/10.1016/S0378-4290(00)00072-1

[47] Olfs, H.W. (2009) Improved Precision of Arable Nitrogen Applications; Requirements, Technologies and Implementation. Proceedings 662, International Fertiliser Society, York, 36 p.

[48] D’Haene, K.D., Salomez, J., De Neve, S., De Waele, J. and Hofman, G. (2014) Environmental Performance of Nitrogen Fertiliser Limits Imposed by the EU Nitrates Directive. Agriculture, Ecosystems and Environment, 192, 67-79. http://dx.doi.org/10.1016/j.agee.2014.03.049

[49] Schröder, J.J., Neeteson, J.J., Withagen, J.C.M. and Noij, I.G.A.M. (1998) Effects of N Application on Agronomic and Environmental Parameters in Silage Maize Production on Sandy Soils. Field Crops Research, 58, 55-67. http://dx.doi.org/10.1016/S0378-4290(98)00086-0 
Scientific Research Publishing (SCIRP) is one of the largest Open Access journal publishers. It is currently publishing more than 200 open access, online, peer-reviewed journals covering a wide range of academic disciplines. SCIRP serves the worldwide academic communities and contributes to the progress and application of science with its publication.

Other selected journals from SCIRP are listed as below. Submit your manuscript to us via either submit@scirp.org or Online Submission Portal.
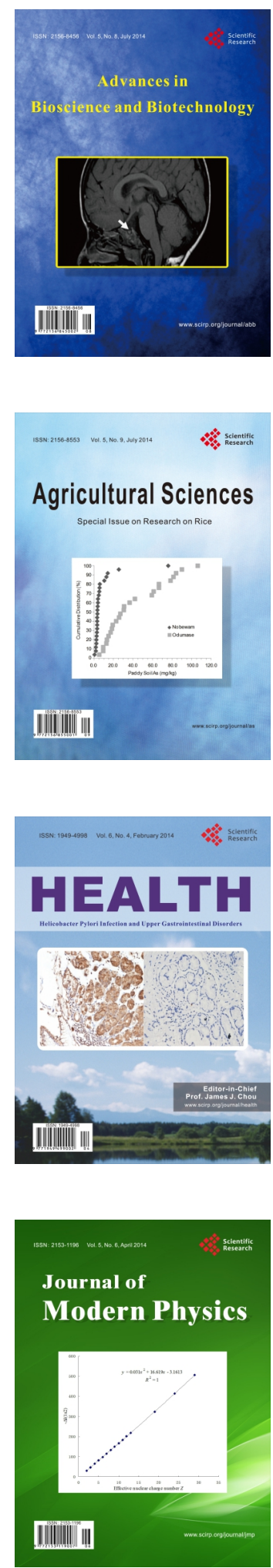
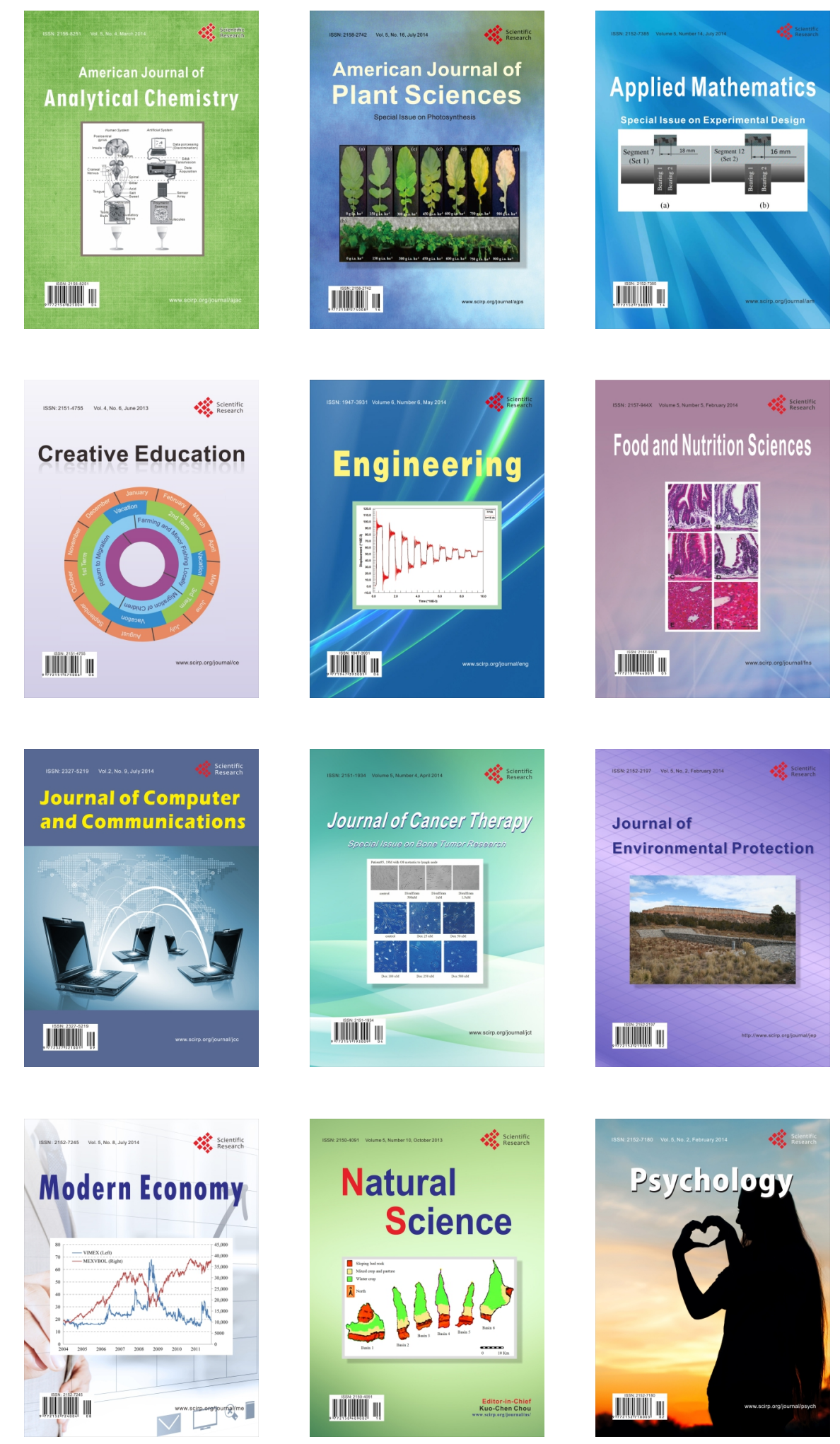